\title{
Valuations of Elemental Concentrations of Particle Matter in Ulaanbaatar, Mongolia
}

\author{
N. Amgalan1, T. Narantsetseg1, D. Shagjjamva² \\ ${ }^{1}$ Department of Chemistry, School of Arts and Science, University of Mongolia, Ulaanbaatar, Mongolia \\ ${ }^{2}$ Nuclear Research Center, Ulaanbaatar, Mongolia \\ Email: n_amgalan@num.edu.mn
}

How to cite this paper: Amgalan, N., Narantsetseg, T. and Shagjjamva, D. (2016) Valuations of Elemental Concentrations of Particle Matter in Ulaanbaatar, Mongolia. Open Journal of Air Pollution, 5, 160-169. http://dx.doi.org/10.4236/ojap.2016.54012

Received: August 22, 2016

Accepted: December 20, 2016

Published: December 23, 2016

Copyright $\odot 2016$ by authors and Scientific Research Publishing Inc. This work is licensed under the Creative Commons Attribution International License (CC BY 4.0).

http://creativecommons.org/licenses/by/4.0/

\begin{abstract}
This study focused on the contents of the air particulate matter pollution in two districts of Ulaanbaatar and determined the chemical composition of air borne samples and the source of those particles. Samples of fine and coarse fractions of PM were collected using a "Gent" stacked filter unit in two fractions of $0-2.2 \mu \mathrm{m}$ and $2.2-10$ $\mu \mathrm{m}$ sizes in two semi-residential areas from September 2012 to August 2013. This paper points out that fine and coarse concentration varied seasonally with meteorological changes. In sampling site 3, Zuun Ail (Figure 1) combustion generators generate the majority of pollution around $50.6 \%$ of household waste furnace to create high-temperature combustion of $21.6 \%$. However, this net contributes to soil contamination near the lower value $(5 \%)$ that arises around the vacuum environment in substantial amounts (14\%), where is open around the buildings and residential areas, and the soil is considered to be due to the construction. But the data point to the highway in the distance, where is $9 \%$ of contamination of all vehicles' smoke, and exhaust is similar to the data collected in Ulaanbaatar. According to analysis of samples of Nuclear Research Center (NRC) sampling site 2, it shows burning source of Particulate Matter 2.5 pollution in the air is around $25.5 \%$ of household waste furnace to create high-temperature product of combustion. But here the very high net contribution to the pollution of soil, is $31.6 \%$. Today's emerging dust is around $15.2 \%$, showing that motor vehicle pollution causes $19.7 \%$. Since the analysis was done on a sample-by-sample basis, it is possible to estimate the daily contributions of pollution sources and provide useful information based on a limited number of samples in order to address air quality management issues in Ulaanbaatar.
\end{abstract}

\section{Keywords}

Pollution, Emission Source, Combustion, Particulate Matter, Dust Composition, Elemental Concentrations 


\section{Introduction}

Daily life is interconnected to environmental change and air quality. Today, pollution is one of the world's most important issues. In recent years, air quality concerns have become one of the most important problems to be solved for the capital city of Mongolia, Ulaanbaatar (UB). Located at approximately 1300 meters above sea level, the coldest national capital in the world, UB has an average annual temperature of $-1.3^{\circ} \mathrm{C}\left(29.7^{\circ} \mathrm{F}\right)$, and population of 1.8 million [1].

Particulate matter (PM) air pollution in Ulaanbaatar is several times higher than the permissible level of the Mongolian National Air Quality Standards 4585:2007 (MNS) and the World Health Organization (WHO) standards. Ulaanbaatar was ranked in the list of the most polluted cities of the world by the World Bank.

With special focus on particulate matter, the secondary PM consists of significant portions of sulfates and nitrates, which are due to chemical transformation of $\mathrm{SO}_{2}$ and $\mathrm{NO}_{\mathrm{x}}$. Of these pollutants, the $\mathrm{PM}$ is one of the most critical, responsible for the largest healthy and economic damages and also affects in visibility and weather condition.

Fine particles $\left(\mathrm{PM}_{2.5}\right)$ are mainly from combustion sources like vehicles, diesel engines and industrial facilities. Coarse particles are directly emitted from activities that distract the soil including travel on roads, construction, mining, open burning and agricultural operations. Other sources include windblown dust, pollen, salts, brake dust and tire wear [2].

The purpose of this study is to investigate particulate matter air pollution in UB, and to compare it with research conducted in 2008, and determine the level of chemical elemental composition and black carbon (BC) concentration data. The PM samples were collected at two semi-residential sites in UB. The local source profiles used in this analysis were obtained from a previous data analysis study [3] and the data set used for the analysis is from September 2012 through August 2013 at Zuul Ail and the NRC.

Previous work mainly focused on sampling in the Zuun Ail location. The same equipment was used in this study as was used in the previous research, but a second sampling site for comparison was chosen. That is why we have to do this research and compare it with meteorological conditions and monitor how depends on it.

By comparing the results of two-point measurements of the city with the results of September 2012 to August 2013, the annual average concentration of $\mathrm{PM}_{2.5}$ decreased by $58 \%$ from $296.5 \mu \mathrm{g} / \mathrm{m}^{3}$ to $123.5 \mu \mathrm{g} / \mathrm{m}^{3}$ and the an annual average concentrations of $\mathrm{PM}_{10}$ decreased by $50 \%$ from $557.5 \mu \mathrm{g} / \mathrm{m}^{3}$ to $276.1 \mu \mathrm{g} / \mathrm{m}^{3}$, and it appears that measures taken by the parliament and the national government, as well as the city government may have reduced air pollution.

The results of the research work have been compared with those obtained from PM analysis performed in an earlier study [4] and to determine the changes of the seasonal process of air particulate matter pollution of the city and its mitigation measures of the basis for the development of practical importance, and to explore the source of those particles. 


\section{Methods and Materials}

Our study of changes in the elemental concentration of $\mathrm{PM}_{2.5}$ and $\mathrm{PM}_{10-2.5}$ in two districts of UB began in September 2012 and ended in August 2013. The research was conducted at the 2 points for 2 times in a 24 hour period.

\subsection{Study Area}

In this study PM samples were collected at two semi-residential sites in UB (Figure 1). Population growth, caused mainly by rural to urban migration has led to major increases in the capital city's air pollution emissions. Much of the population growth has been in the city's low-income ger (traditional Mongolian residence) districts such as Zuun ail where coal and wood are burned for heat. Specified the long winters, coal use for cooking and heating is widespread and the principal cause of air pollution.

Previous work (from 2008 to 2009) [4] mainly focused on sampling in the same location.

\subsection{Sampling}

Sampling was done using a "Gent" type stacked filter sampler [5].

A portable particle analyzer, known as an optical particle counter (OPC, Model 1.108, GRIMM Inc.), specifically designed for $\mathrm{PM}_{2.5}$ and $\mathrm{PM}_{10}$ ambient air sampling in the present study. Collecting fraction samples of particulate matter in the coarse particles $\left(\mathrm{PM}_{10}\right)$ and fine particulates $\left(\mathrm{PM}_{2.5}\right)$ size have been monitored using the GRIMM sampler.

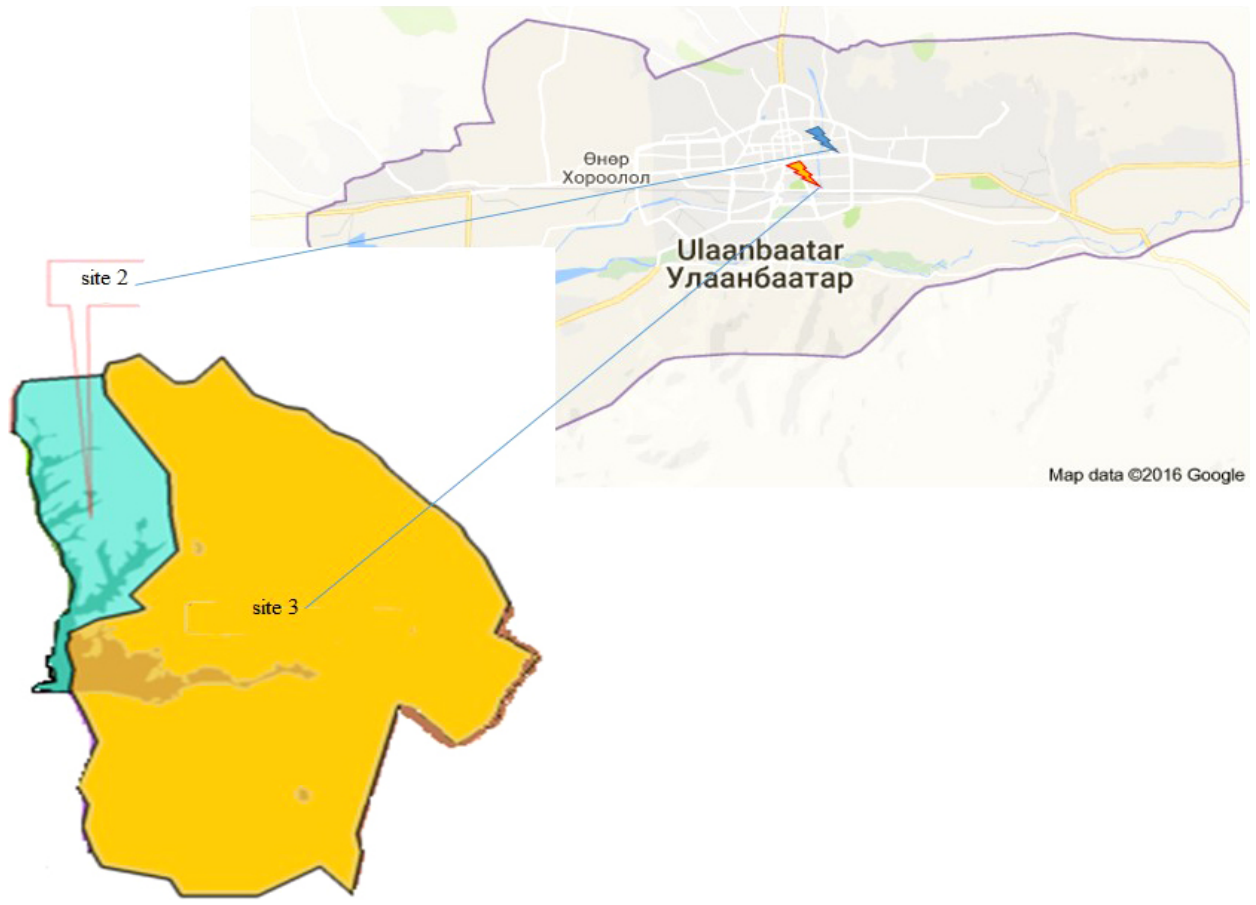

Figure 1. Locations of the air samples in Ulaanbaatar area (site 2. NRC, NUM and site 3. Zuun Ail). 
The research to collect air particulate matter two extract fraction samples has the special work tapes, and fractions uses were collected GENT air pump system for sampling, and polycarbonate filter with $2 \mathrm{~mm}$ thick, $8 \mathrm{~mm}$ to filter $\mathrm{PM}_{10-2.5}$ large particles and $0.4 \mathrm{~mm}$ hole filtration to filter less than $\mathrm{PM}_{2.5}$ micron diameter air particulate matter.

\subsubsection{Determination of PM Mass and BC}

The masses of the coarse and fine fraction samples were determined by balancing the filters before and after the exposure. The concentration of $\mathrm{BC}$ in the fine fraction of the samples is determined by reflectance measurement using an EEL-type Smoke Stain Reflectometer.

\subsubsection{Multi Element Analysis}

Air samples have been determined and elemental concentrations were measured by RFA using SPESTRO XEPOS spectrometer and up to 20 chemical elements have been identified from $\mathrm{Na}$ to $\mathrm{U}$. The contamination source has been determined by the result of element analysis. Data on the concentrations of sixteen species, BC and mass were available for further analysis. To this end, research was done on the data based on multivariate statistical methods used SPSS 22 program.

\subsubsection{Metrological Condition}

The meteorological data used in this study was obtained from a local meteorological station.

\section{Results and Discussion}

\subsection{The Contamination Concentration of Air Particulate Matter Pollution in Ulaanbaatar}

At the Zuun Ail and NRC measurement point coarse and fine particle concentrations were collected to provide measurements during the period of September 2012 to August 2013. $\mathrm{PM}_{10-2.5}$ and $\mathrm{PM}_{2.5}$ fraction measurement samples determined the amount of $\mathrm{PM}$ air pollution in UB. The results are shown in Table 1.

Particulate matter concentrations were found to be extremely high at times with average $\mathrm{PM}_{10}$ concentrations measured at $276.1 \mu \mathrm{g} / \mathrm{m}^{3}$ and $\mathrm{PM}_{2.5}$ concentrations measured at $123.5 \mu \mathrm{g} / \mathrm{m}^{3}$ in the Zuun Ail respectively (the Guidelines recommends $10 \mu \mathrm{g} / \mathrm{m}^{3}$ for fine, and $20 \mu \mathrm{g} / \mathrm{m}^{3}$ for coarse).

Table 1. $\mathrm{PM}_{2.5}$ and $\mathrm{PM}_{10}$ concentrations at sampling areas.

\begin{tabular}{|c|c|c|c|c|}
\hline \multirow{3}{*}{$\mathrm{PM}$} & \multicolumn{2}{|c|}{ Average concentrations of the $\mathrm{PM}\left(\mu \mathrm{g} / \mathrm{m}^{3}\right)$} & \multirow{3}{*}{ MNS 4585:2007 } & \multirow{3}{*}{$\begin{array}{c}\text { Air Quality Guidelines } \\
\text { WHO, } 2005\end{array}$} \\
\hline & Zuun Ail & NRC & & \\
\hline & 2012-2013 & $2012-2013$ & & \\
\hline $\mathrm{PM}_{2.5}$ & 123.5 & 117.5 & 25 & 10 \\
\hline $\mathrm{PM}_{10}$ & 276.1 & 263.7 & 50 & 20 \\
\hline
\end{tabular}


Fine particle average annual concentration was measured at $123.5 \mu \mathrm{g} / \mathrm{m}^{3}$ and 117.5 $\mu \mathrm{g} / \mathrm{m}^{3}$. MNS 4585:2007 specified in $\left(25 \mu \mathrm{g} / \mathrm{m}^{3}\right) 4.9$ greater than, $\left(50 \mu \mathrm{g} / \mathrm{m}^{3}\right)$ again 4.7 greater than, WHO Air Quality Guidelines from size $\left(10 \mu \mathrm{g} / \mathrm{m}^{3}\right) 12.35$ greater than, 11.75 greater than recommended standard respectively (Table 1 ).

There is high air pollution from October through May and extremely high air pollution from January through March. Fine particle concentration peaked during the winter (December, January, March). The monthly average concentration of $\mathrm{PM}_{10}$ is relatively higher $576.9 \mu \mathrm{g} / \mathrm{m}^{3}$ than $549.9 \mu \mathrm{g} / \mathrm{m}^{3}$. The average concentration of the other months is from January to May. The average monthly maximum in 2012-2013 from June through October had uniformly low concentration levels. Air pollutant concentration at the surface is strongly influenced by the characteristics of the source emission and the meteorological conditions of the atmosphere [6].

According to Figure 2, depending on the ambient temperature during the cold seasons, air pollution increased from December to March. The PM generated from coal consumption grew and thus caused the incomplete combustion of coal around Zuun Ail households. Also there is high air pollution in March (large particulate matter 294.9 $\left.\mu \mathrm{g} / \mathrm{m}^{3}\right)$. This may be the result of dust as shown in Figure 3 .

Three meteorological and 12 hour radio-sound data weather charts were used to characterize the atmospheric conditions in UB during the measurement period of September 2012 to August 2013.

\subsection{Determination of Elemental Concentrations in the Air Particulate Matter Samples}

At both Zuun Ail and NRC sites fractions of 20 chemical elements in the ambient air $\mathrm{PM}_{2.5}$ samples and $\mathrm{PM}_{10-2.5}$. Si, $\mathrm{Al}, \mathrm{Ca}, \mathrm{Fe}$, Ti were found in the soil-derived components, such these are considered as high-grade (Table 2).

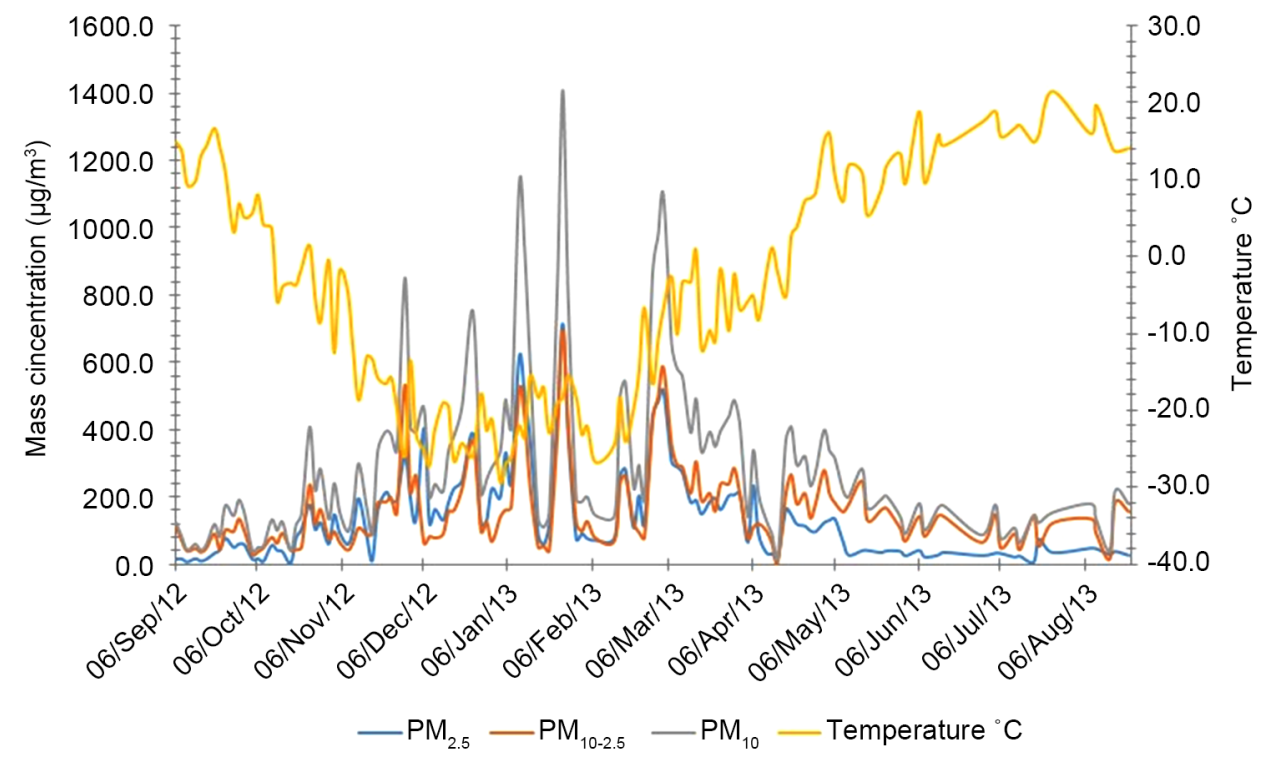

Figure 2. $\mathrm{PM}_{2.5}, \mathrm{PM}_{10-2.5}$ Zuun Ail concentration is in a temperature-dependent relationship. 


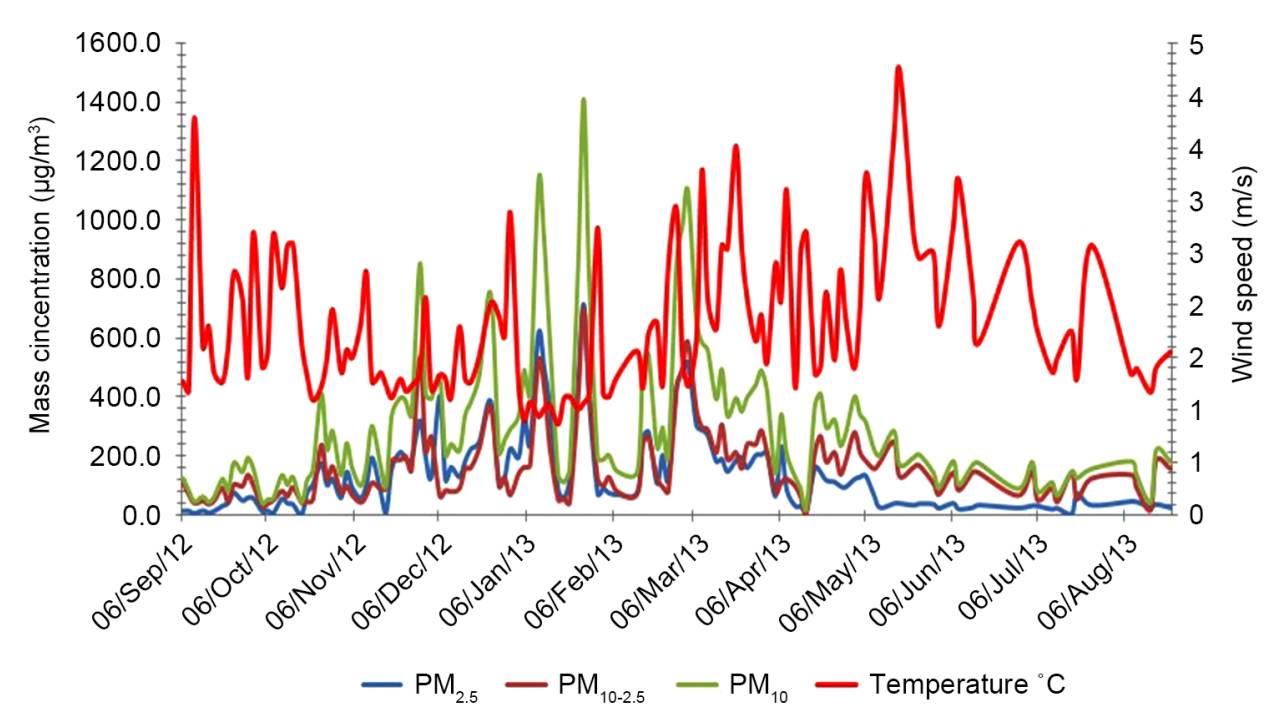

Figure 3. $\mathrm{PM}_{2.5}, \mathrm{PM}_{10-2.5}, \mathrm{PM}_{10}$ Zuun Ail concentration with wind speed dependent.

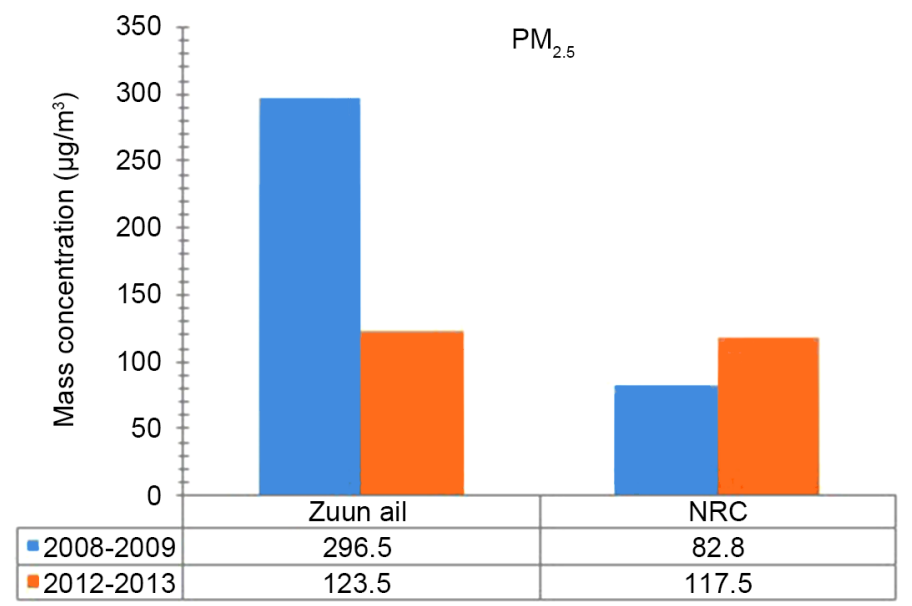

(a)

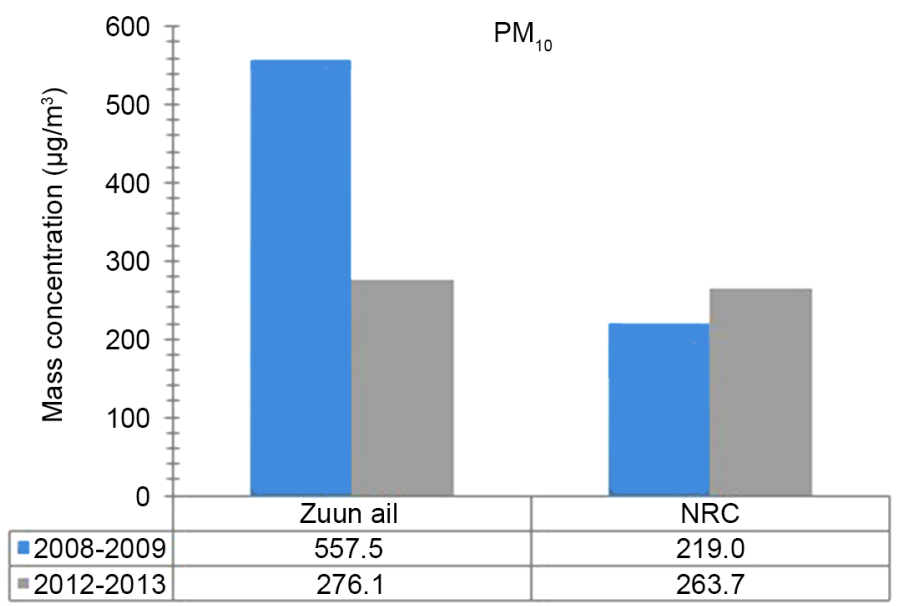

(b)

Figure 4. (a) $\mathrm{PM}_{2.5}$ mass concentrations compared to the previous year from 2008 to 2009. (b) $\mathrm{PM}_{10}$ mass concentrations compared to the previous year from 2008 to 2009 . 
Table 2. The average elemental concentration of particulate matter, 2012-2013.

\begin{tabular}{|c|c|c|c|c|}
\hline \multirow{3}{*}{ Elements } & \multicolumn{4}{|c|}{ Average concentrations in $\left(\mathrm{ng} / \mathrm{m}^{3}\right)$} \\
\hline & \multicolumn{2}{|c|}{ Zuun Ail } & \multicolumn{2}{|c|}{ NRC } \\
\hline & $\mathrm{PM}_{2.5}$ & $\mathrm{PM}_{10-2.5}$ & $\mathrm{PM}_{2.5}$ & $\mathrm{PM}_{10-2.5}$ \\
\hline Mass & 133,654 & 155,762 & 117,452 & 146,259 \\
\hline $\mathrm{BC}$ & 5586 & 2373 & 8685 & 3482 \\
\hline $\mathrm{Na}$ & 1940 & 3858 & 3017 & 5778 \\
\hline $\mathrm{Mg}$ & 600 & 2197 & 1040 & 3383 \\
\hline $\mathrm{Al}$ & 1211 & 7903 & 2119 & 13,382 \\
\hline $\mathrm{Si}$ & 1629 & 14,423 & 3442 & 25,153 \\
\hline $\mathrm{P}$ & 260 & 333 & 282 & 360 \\
\hline$S$ & 3868 & 2036 & 5824 & 2412 \\
\hline $\mathrm{Cl}$ & 300 & 661 & 361 & 891 \\
\hline $\mathrm{K}$ & 244 & 1567 & 392 & 2795 \\
\hline $\mathrm{Ca}$ & 309 & 3180 & 713 & 5546 \\
\hline $\mathrm{Ti}$ & 143 & 315 & 159 & 481 \\
\hline $\mathrm{Mn}$ & 57 & 105 & 63 & 151 \\
\hline $\mathrm{Fe}$ & 269 & 2254 & 495 & 3962 \\
\hline $\mathrm{Cu}$ & 12 & 21 & 13 & 22 \\
\hline $\mathrm{Zn}$ & 47 & 49 & 68 & 69 \\
\hline $\mathrm{Pb}$ & 17 & 6 & 26 & 13 \\
\hline
\end{tabular}

Near the NRC site there was fine particulate pollution $\left(\mathrm{PM}_{2.5}\right)$ and the samples contained a high level of $\mathrm{BC}$ and sulfur (S) and the products of combustion. The combustion was from the small scale stoves and also the smoke from the thermal plant. It shows high concentration levels of elements (Table 2). The results of the samples show there are basic elements $\mathrm{Al}, \mathrm{Si}, \mathrm{Ca}, \mathrm{Ti}$ and $\mathrm{Fe}$ which constitute soil and these dominate in both fine and coarse particles in the atmosphere. Airborn soil originating from crystal matter is dominated by $\mathrm{Al}$ and $\mathrm{Si}$ along with $\mathrm{Ca}, \mathrm{Ti}$ and $\mathrm{Fe}$. However, this is not only caused by the dust from the soil, the wind, but most of these elements are especially fine particles of combustion products that are related to human activities and the fine fraction contains elements. In addition, $\mathrm{Na}, \mathrm{Mg}, \mathrm{P}, \mathrm{Mn}$ elements were contained in all the samples and in a mixture of the soil. $\mathrm{Ni}, \mathrm{Cu}, \mathrm{Zn}$ and $\mathrm{Pb}$ are also contained in all samples, but heavy elements were detected in the relatively large number of samples and those are usually contained in soil and generate from motors of vehicles, emission of vehicle brake parts, and garbage combustion. There are two distinct coal combustion source types present in the UB combustion characteristics. 


\subsection{Identifying the Source of Air Particulate Matter Pollution and to Define Its Contributions to Air Pollution}

Figure 5 is made by EMF analysis using the elemental analysis results in the air samples. Through the analysis of positive matrix factoring, Soil, Combustion-1 (furnace), Combustion-2 (power plant, small size stove, BC), Dust (buildings and roadwork and other) and Vehicles, there are five patterns of pollution sources that have been identified. The average mass contributions of each of the sources to ambient coarse particle concentration are shown in Table 3 and the source profiles are presented in Figure 5.

Table 3 presents the comparison of the estimated average source contribution obtained from EMF analysis for the fine PM using the same chemical composition data sets of all the samples. In the case of fine PM, several differences were noted.

Around the NRC there may have been a lot of pollution from the soil. This profile contains $\mathrm{S}$ and $\mathrm{BC}$ as well as other soil components [7]. Air pollution related to human activities indicates similar results showing in the two locations. In the location around Zuun Ail and it is surrounding areas, there is re-development of ger districts and new
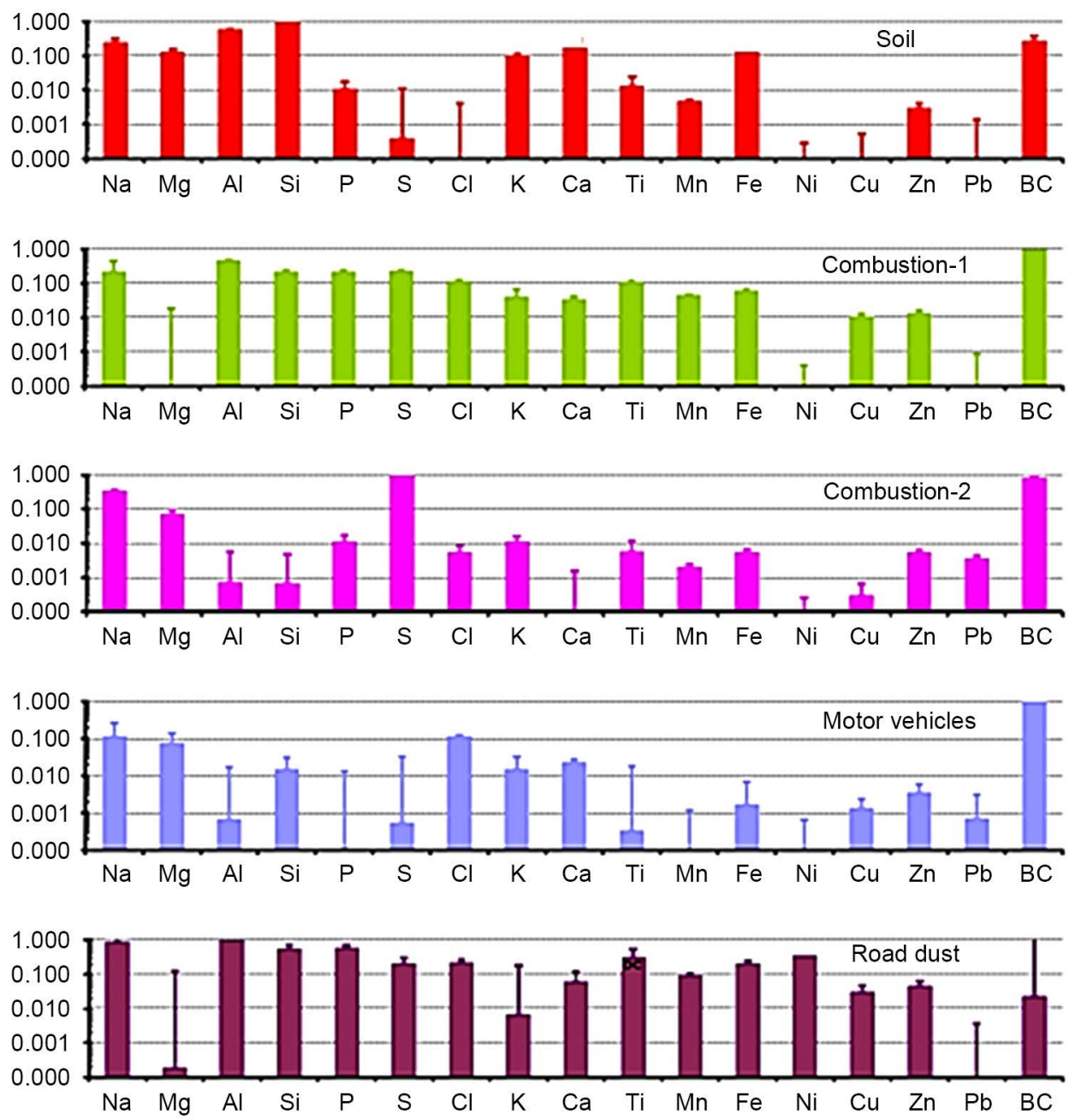

Figure 5. Source related classification of the elements profiles for $\mathrm{PM}_{2.5}$ samples. 
Table 3. Measurement of $\mathrm{PM}_{2.5}$ particles in its source point pollution contribution.

\begin{tabular}{cccc}
\hline & & \multicolumn{2}{c}{ Contribution to pollution (\%) } \\
\cline { 3 - 4 } & $\mathrm{PM}_{2.5}$ source of pollution & NRC & Zuun Ail \\
\cline { 3 - 4 } 2 & Combustion-1 & 25.5 & 50.6 \\
3 & Combustion-2 & 8.1 & 21.6 \\
4 & Soil & 31.6 & 4.9 \\
5 & Road dust & 15.2 & 13.9 \\
\hline
\end{tabular}

buildings, and around the location of NRC there is construction in progress. In proximity to this point there are dusty road passes. For the vehicles near the NRC there is an east route and central road of the city that passes on either side (Table 3). The motor vehicle (mixed diesel and gasoline engine exhaust) source profile is characterized by the high $\mathrm{BC}$ and S [3]. This source is also mixed with the crustal elements, $\mathrm{Mg}, \mathrm{Al}, \mathrm{Si}$, and Fe, suggesting the vehicular exhaust is mixed with re-suspended road dust.

\section{Conclusions}

Particulate matter $\left(\mathrm{PM}_{2.5}\right)$ annual average concentration is $123.5 \mu \mathrm{g} / \mathrm{m}^{3}$ and $117.5 \mu \mathrm{g} / \mathrm{m}^{3}$ and it has 5 times more than MNS 4585:2007 allowing, and $11-12.5$ times more than the measurement specified from the Air Quality Counsel of WHO. The annual average concentration of $\mathrm{PM}_{10}$ is $276.1 \mu \mathrm{g} / \mathrm{m}^{3}$ and $263.7 \mu \mathrm{g} / \mathrm{m}^{3}$ and it is $5.2-5.8$ times higher than Mongolian standards, 13.2 - 14.5 times higher than the amount specified from the Air Quality Counsel. In this research, for the population health assessment of the air quality, the indexes of 2 points indicate at a high risk for health.

In addition, air pollution may depend on the wind. From January through March Ulaanbaatar has the highest concentration than other months. Wind speed is constant in the cold seasons and it increases in March and it may be the reason for the increase in soil and dust emissions.

An EMF analysis result shows UB's air pollution sources in the territory of the two different points have variety as shown by the data.

Measures to reduce air pollution in the city not from smoking, but from other sources are necessary. Dust should be regarded as a defined contribution source of particulate pollution.

\section{Acknowledgements}

We acknowledge the support provided by professor (Ph.D) S. Lodoisamba, NRC of National University of Mongolia (NUM) and the anonymous referees for their useful comments on earlier drafts of this paper.

AN was supported by high-tech grants (NO. ӨC 2015 ШУC 12) from the NUM for research. 


\section{References}

[1] Allen, R.W., et al. (2013) An Assessment of Air Pollution and Its Attributable Mortality in Ulaanbaatar, Mongolia. Air Quality, Atmosphere and Health, 9, 137-150.

[2] Begum, B.A., et al. (2004) Investigation of the Sources of Atmospheric Aerosol at Urban and Semi-Urban Areas in Bangladesh. Atmospheric Environment, 2, 42. https://doi.org/10.1016/j.atmosenv.2004.02.042

[3] Salako, G.O., et al. (2012) Exploring the Variation between EC and BC in a Variety of Locations. Aerosol and Air Quality Research, 12, 1-7. https://doi.org/10.4209/aaqr.2011.09.0150

[4] Davy, P.K., et al. (2011) Air Particulate Matter Pollution in Ulaanbaatar, Mongolia: Determination of Composition, Source Contributions and Source Locations. Atmospheric Pollution Research, 2, 126-137. https://doi.org/10.5094/APR.2011.017

[5] Hopke, P. (1985) The Use of Chemometrics in Apportionment of Air Pollution Sources. Trends in Analytical Chemistry, 4, 104-106. https://doi.org/10.1016/0165-9936(85)87075-8

[6] Batmunkh, T., Kim, Y.J., Jung, J.S., Park, K. and Tumendemberel, B. (2013) Chemical Characteristics of Fine Particulate Matters Measured during Severe Winter Haze Events in Ulaanbaatar, Mongolia. Journal of the Air \& Waste Management Association, 63, 659-670.

[7] Boulter, P. (2006) A Review of Emission Factors and Models for Road Vehicle Non-Exhaust Particulate Matter. pp. 81.

Submit or recommend next manuscript to SCIRP and we will provide best service for you:

Accepting pre-submission inquiries through Email, Facebook, LinkedIn, Twitter, etc. A wide selection of journals (inclusive of 9 subjects, more than 200 journals)

Providing 24-hour high-quality service

User-friendly online submission system

Fair and swift peer-review system

Efficient typesetting and proofreading procedure

Display of the result of downloads and visits, as well as the number of cited articles

Maximum dissemination of your research work

Submit your manuscript at: http://papersubmission.scirp.org/

Or contact ojap@scirp.org 